\title{
Natural Cytotoxicity Triggering Receptor 3 Ligand 1
}

National Cancer Institute

\section{Source}

National Cancer Institute. Natural Cytotoxicity Triggering Receptor 3 Ligand 1. NCI

Thesaurus. Code C118530.

Natural cytotoxicity trigg ering receptor 3 ligand 1 ( $454 \mathrm{aa}, \sim 51 \mathrm{kDa}$ ) is encoded by the human NCR3LG1 gene. This protein is involved in the activation of natural killer cellmediated cytotoxicity. 